\title{
Out of the Ordinary: Confronting Paradox in the Historiography of Francoism
}

\author{
Stephanie Wright \\ Department of History, Classics and Archaeology, Birkbeck, University of London, 26 Russell Square, Room B33, \\ London WC1B 5DQ, UK \\ Stephanie.wright@bbk.ac.uk
}

José Babiano, Gutmaro Gómez, Antonio Míguez and Javier Tebar, Verdugos Impunes: El Franquismo y la Violación Sistémica de los Derechos Humanos (Barcelona: Ediciones de Pasado y Presente, 2017). 285pp. (pb), €22, ISBN: 978-84-947694-3-6.

David Brydan, Franco's Internationalists: Social Experts and Spain's Search for Legitimacy (Oxford: Oxford University Press, 2019). $\mathrm{x}+204 \mathrm{pp}$. (hb), £60, ISBN: 978-0-19-883459-5.

Asunción Esteban, Dunia Etura, Matteo Tomasoni, eds., La Alargada Sombra del Franquismo: Naturaleza, Mecanismos de Pervivencia y Huellas de la Dictadura (Granada: Editorial Comares, 2019). xxii +440pp. (pb), €41.80, ISBN: 978-84-9045-790-0.

Carlos Fuertes Muñoz, Viviendo en dictadura: La evolución de las actitudes sociales hacia el franquismo (Granada: Editorial Comares, 2017). xvi + 288pp. (pb), €28.50, ISBN: 978-84-9045-414-5.

Enrique Moradiellos, Franco: Anatomy of a Dictator (London: I.B. Tauris, 2018). xiv +246pp. (hb), £21, ISBN: 978-1-78453-942-9.

Manuel Ortiz Heras, ed., ¿Qué sabemos del Franquismo? Estudios para Comprender la Dictadura de Franco (Granada: Editorial Comares, 2018). xxiii + 288pp. (pb), €23.75, ISBN: 978-84-9045-717-7.

Julio Prada Rodríguez, The Plundering of the Vanquished: The Economic Repression during Early Francoism (Berlin: Peter Lang, 2019). 198pp. (hb), £31, ISBN: 978-3-631-78598-0.

On 19 November 1975 Francisco Franco lay dying in Madrid's La Paz hospital. Clutching the cloak of the Virgin del Pilar, and with the ill-gotten relic of St Teresa of Ávila's hand at his bedside, the ailing dictator would soon depart this existence following the withdrawal of life support. For Enrique Moradiellos in Franco: Anatomy of a Dictator, the juxtaposition of modernity and tradition within this deathbed scene was emblematic of the countless paradoxes which characterised the Francoist dictatorship in its later years. ${ }^{1}$ Since the dictator's death scholars have continued to grapple with such paradoxes, struggling over how best to define a regime which has come to occupy a notoriously contentious space within contemporary Spanish politics and society. Like a fairground hall of mirrors, historical representations of Francoism have been stretched or squashed by different analytical frames, shaped in many cases by the political and social legacies of the dictatorship. Despite dubious claims to 'objectivity', the regime's apologists depict Francoism as a stabilising antidote to the 'chaos' of republicanism, conveniently overlooking the destruction and misery which followed the coup of 18 July $1936 .{ }^{2}$

\footnotetext{
1 Enrique Moradiellos, Franco: Anatomy of a Dictator (London: I.B. Tauris, 2018), 94.

2 For a critique of some recent examples, see Chris Ealham, 'Review: The Emperor's New Clothes: "Objectivity" and Revisionism in Spanish History', Journal of Contemporary History, 48, 1 (2013), 191-202. The continuing influence of

(c) The Author(s), 2021. Published by Cambridge University Press. This is an Open Access article, distributed under the terms of the Creative Commons Attribution licence (http://creativecommons.org/licenses/by/4.0/), which permits unrestricted re-use, distribution, and reproduction in any medium, provided the original work is properly cited.
} 
Meanwhile, those who seek justice for the regime's victims continue to emphasise the repressive nature of the dictatorship. ${ }^{3}$ Though an important component of Francoism's modus operandi, repression does not, by itself, help us to fully understand Francoism's long-term survival or the consent it secured from millions of ordinary Spaniards. The titles under review reflect an increasing willingness to confront Francoism's many contradictions head-on, and to regard the paradoxical nature of the regime not as a conceptual knot to be disentangled, but as a historiographical problem in itself. ${ }^{4}$ Historians exploring the experiences of 'ordinary' people have proved particularly adept at addressing such complexities, as have scholars adopting comparative or transnational frameworks which reach beyond traditional emphasis on fascist Italy and Nazi Germany. The titles surveyed in this article offer a snapshot of recent developments in the field, while signposting potential avenues through which historians of Francoism might contribute to broader discussions within the historiography of modern Europe.

Enrique Moradiellos's Franco: Anatomy of a Dictator contributes to the already extensive literature on the political nature of Francoism. Despite its title, Franco is not so much a biography of the dictator himself but rather a dissection of his dictatorship from three angles: the man, the figure of the 'Caudillo' and the regime. One of the assets of this highly readable account is Moradiellos's detailed analysis of the origins of Franco's positioning as 'Caudillo' of Spain. The term 'caudillo', commonly used to refer to the commanders of Spain's nineteenth- and early twentieth-century colonial wars, was initially attributed to a number of leaders on the rebel side in the Spanish Civil War, before it crystallised into the singular, capitalised form upon Franco's ascendancy to the head of the rebellion in September 1936. Moradiellos pays particular attention to the role of Francoist jurists in legitimising the notion of 'charismatic personality' (in the Weberian sense) as the basis for Franco's authority. Legal scholars such as Luis del Valle Pascual insisted that in contrast to constitutional 'democracies of individuals', in an 'organic democracy' like Spain's, the head of state was chosen 'by the will expressed by the people by enthusiastic acclamation or by plebiscite' and would become 'supreme leader and director, commander and guide of the people'. ${ }^{5}$ While having the advantage of bringing coherence to a regime balancing a number of competing factions, the 'charismatic' nature of Franco's caudillaje ultimately contributed to the dictatorship's undoing. No amount of legal windowdressing could disguise the fact that a regime under which 'it is known who commands, but ignored who has the right to command' would always lack the moral legitimacy necessary to survive within the liberal and democratic contemporary West. $^{6}$

Moradiellos then builds on this careful discussion of the 'Caudillo' to offer an authoritative assessment of Francoism, particularly its position within the broader context of twentieth-century European fascism. Contrary to the claims of some contemporary commentators, 'Caudillo' was not simply a 'bad translation of Führer', and Moradiellos underscores the limitations of fascism as an analytical framework for understanding the at once military, Catholic and traditionalist Francoist regime. ${ }^{7}$ Offering an overview of the different ways in which Francoism has been conceptualised over the years, from Linz's 'authoritarian' thesis in the 1960s to the concept of a 'fascistized' regime more recently championed by Ismael Saz, Moradiellos concludes that 'the dominant perception now that [sic] it was a military dictatorship first fascistized and then transformed into an essentially authoritarian regime, despite

Francoism over Spanish society, politics and judicial institutions is often referred to as 'sociological Francoism', and is discussed in Emilio Silva Barrera, 'Todos somos franquismo sociológico' in Asunción Esteban, Dunia Etura, Matteo Tomasoni, eds., La Alargada Sombra del Franquismo: Naturaleza, Mecanismos de Pervivencia y Huellas de la Dictadura (Granada: Editorial Comares, 2019), 319-29.

3 José Babiano, Gutmaro Gómez, Antonio Míguez and Javier Tebar, Verdugos Impunes: El Franquismo y la Violación Sistémica de los Derechos Humanos (Barcelona: Ediciones de Pasado y Presente, 2017).

4 Ismael Saz, 'Prólogo' in Carlos Fuertes Muñoz, Viviendo en dictadura: La evolución de las actitudes sociales hacia el franquismo (Granada: Editorial Comares, 2017), xiii.

5 Moradiellos, Franco, 142.

6 Ibid., 146.

7 Salvador de Madariaga, General, Márchase Usted (New York: Ibérica, 1959), 15, cited in Moradiellos, Franco, 161. 
the fascistic features which remained until the end'. ${ }^{8}$ What is clear for Moradiellos is that throughout the twists and turns, stagnation and reinvention of Francoism, the only real defining constant of the regime as a political entity was 'the presence of General Franco as caudillo and dictator with sovereign powers' by the grace of God.'

While this conclusion is not innovative, as Moradiellos himself intimates in the book's final pages, what is particularly refreshing about Franco is its framing within current discussions over popular historical memory of the dictatorship. ${ }^{10}$ While acknowledging the long political shadow of the regime, Moradiellos points to the surprising ambiguity of Spanish popular opinion towards Franco, 'quite unlike the Germans' demonization of Hitler. ${ }^{11}$ Despite his omnipresence over the course of nearly four decades, Moradiellos remarks upon Spaniards' 'virtual forgetting of the Caudillo', which he attributes not necessarily to 'the political cautiousness of the defeated left-wing', but rather to 'the ideological and historical anachronism of the extreme alternatives faced during the Civil War and the inability of Spanish citizens to identify with any of them personally, totally and exclusively. ${ }^{12}$ This draws attention to the nuances of Franco's (non?)legacy, and brings a sense of perspective to Spain's on-going historical memory wars while repositioning ordinary Spaniards at the centre of broader discussions of the dictatorship. Those looking for an exhaustive account of the dictator's life might still reach for Paul Preston's 1993 biography, but as a vivid and wonderfully succinct introduction to the dictator, the dictatorship and the public and historiographical discussions surrounding both of these, Franco: Anatomy of a Dictator will be of value to both academic and popular audiences.

The limitations of comparisons with Nazi Germany and fascist Italy are also raised by a number of contributors within the two edited collections under review. Conceived as a commemoration of the career of Professor $M^{a}$ Encarna Nicolás Marín at the University of Murcia, Manuel Ortiz Heras's ¿Qué sabemos del franquismo? does not engage with the professor's work in depth but rather frames itself as 'a sample of our work to pay her much deserved professional recognition'. ${ }^{13}$ As such, the volume is underwhelming in its overall coherence, but does nonetheless contain some noteworthy contributions from its stellar cast of authors. In her chapter on social attitudes, for example, Ana Cabana Iglesias echoes Moradiellos, pointing to the need for more comparative histories of Francoism which move beyond classic comparisons with Nazi Germany and fascist Italy, to focus on Portugal or other southern European or even Latin American dictatorships. Indeed, despite striking cultural and historical similarities, there are to date few comparative studies of the Iberian dictatorships of the twentieth century, and, to my knowledge, not a single comparative social history of the Spanish and Portuguese cases. ${ }^{14}$ Such comparative scholarship would not only help to reframe current discussions over the

\footnotetext{
8 Moradiellos, Franco, 183. Juan J. Linz, 'An Authoritarian Regime: The Case of Spain', in Erik Nard and Yrjo Littunen, eds., Cleavages, Ideologies, and Party Systems (Helsinki: Westermarck Society, 1964); Ismael Saz, Fascismo y Franquismo (Valencia: Publicaciones de la Universidad de Valencia, 2004).

9 Moradiellos, Franco, 185.

10 Ibid., 197.

11 Ibid., 14.

12 Ibid., 9.

13 Manuel Ortiz Heras, ed., ¿Qué sabemos del Franquismo? Estudios para Comprender la Dictadura de Franco (Granada: Editorial Comares, 2018), xvi.

14 It is worth noting that current works often consider Spain and Portugal in relation to Germany, Italy and the Second World War, rather than seeking to understand the Iberian cases on their own terms. Some examples of existing comparative works include Juan Carlos Jiménez, Franco y Salazar. La respuesta dictatorial a los desafíos de un mundo en cambio 1936-1968 (Madrid: Sílex Ediciones, 2019); Mario Márquez Chaves, La otra mirada: España y Portugal entre el eje y los aliados (Universidad de Extremadura, Servicio de Publicaciones, 2018); António Costa Pintos, A Sombra das Ditaduras. A Europa do Sul em Comparação (Lisbon: Imprensa de Ciências Sociais, 2013); António Costa Pinto and Aristotle Kallis, eds., Rethinking Fascism and Dictatorship in Europe (Hampshire: Palgrave Macmillan, 2014); Juan Carlos Jiménez Redondo, 'La narrativa geopolítica imperial de las dictaduras ibéricas: el régimen de Franco y la desaparición del Estado portugués de la India en 1961', Hispania: Revista española de historia, 79, 263 (2019), 815-46; Pedro Teixeira Pereira, 'Salazar y Franco, la política social ibérica (1933-1957)', Ph.D thesis, Universitat Autònoma de Barcelona, 2013; Rosa Maria Pardo Sanz, 'Las dictaduras ibéricas y el aliado americano en clave de modernización, 1945-1975', Historia y política: Ideas, procesos y movimientos sociales, 34 (2015), 147-79.
} 
nature of Francoism, but would also recentre the history of Spain within broader narratives of European and Atlantic history. Indeed, in his chapter, Antonio Cazorla Sánchez adopts a refreshingly broad comparative lens, widening the frame of analysis to include liberal regimes such as modern Britain and France, whose violence in the colonial context was not so far removed from the crimes of Francoism. Such comparisons do not absolve the Francoist regime of its crimes, but rather help us to reconsider Spanish exceptionalism within modern Europe. As for Franco's survival beyond his German and Italian allies, Cazorla points out that this reflected political developments in other non-belligerent European states in the Second World War, none of which experienced regime change in $1945 .^{15}$

Similar thought provoking interventions appear in Asunción Esteban, Dunia Etura and Matteo Tomasoni's La alargada sombra del franquismo. Again, one might question the need for another 'state-of-the-field' collection which often repackages material published elsewhere (Moradiellos's chapter, for example, is a synthesis of the 'charismatic leadership' thesis outlined above), but there are some valuable pieces within the volume. These include an insightful chapter by Raquel Osborne Verdugo on gay writer and feminist Carmen Alcalde, and some helpful reflections from archivists María del Carmen Rial Quintela and Luis Miguel Rodríguez Alfageme on the many resources which remain untapped within Spain's military and provincial archives. In his article on National Catholicism, Alfonso Botti offers further reflections on the comparative approach, arguing for the need to expand our spatial-temporal lens when analysing National Catholicism to include the role of Catholicism in nationalisms beyond Spain, such as in Poland, Croatia and Argentina. At the same time, comparisons with Nazism remain present, particularly within contributions reflecting on the legacies of Francoism. In the prologue to the volume, for example, journalist Isaías Lafuente attempts to explain the apparent softening of Francoism over time, stating that if Hitler had remained in power for forty years, he would have murdered fewer Jews by the end simply because by then most 'would already have been dead'. ${ }^{16}$ The comparative question speaks to the heart of debates over the nature of Francoism but also reveals tensions between academic scrutiny of the past and the activist imperatives of those seeking justice in the present. Nazism and fascism have become universal bywords for atrocity, and evoking such comparisons can be an effective strategy for communicating to non-academic audiences the injustices and, therefore, striking impunity of Francoist perpetrators of violence. Yet this kind of shorthand is limiting to historians seeking to understand the nature of the regime, its longevity and its fraught sociopolitical legacies. The issue here is not necessarily the German comparison in itself, but rather the underlying assumption that there was ever a full reckoning with the perpetrators of Nazism. In reality, beyond the political elite, most Nazi collaborators never faced justice either. ${ }^{17}$ In Spain, where the roots of Franco's dictatorship were allowed to embed themselves over several generations, and where the transition relied not on revolution or dramatic defeat in war but on careful negotiation between new and old political elites, it is unsurprising that the perpetrators of Francoist violence have never been held to account. ${ }^{18}$ By leaving the more misleading elements of the Nazi/fascist analytical framework behind, it is possible to discuss with greater honesty why many supported the regime, and why many still refuse to condemn it. ${ }^{19}$

15 Antonio Cazorla-Sánchez, 'Una sociedad y una dictadura europeas', in Manuel Ortiz Heras, ed., ¿Qué sabemos del Franquismo? Estudios para Comprender la Dictadura de Franco (Granada: Editorial Comares, 2018), 127.

16 Isaías Lafuente, 'Prólogo', in Asunción Esteban, Dunia Etura, Matteo Tomasoni, eds., La Alargada Sombra del Franquismo: Naturaleza, Mecanismos de Pervivencia y Huellas de la Dictadura (Granada: Editorial Comares, 2019), xvii.

17 See, for example, Mary Fulbrook, Reckonings: Legacies of Nazi Persecution and the Quest for Justice (Oxford: Oxford University Press, 2018).

18 On the terms and consequences of Spain's negotiated transition, see Paloma Aguilar, 'Justice, Politics and Memory in the Spanish Transition', in Alexandra Barahona De Brito, Carmen González Enriquez, and Paloma Aguilar, eds., The Politics of Memory and Democratisation (Oxford: Oxford University Press, 2003), 92-118.

19 Perhaps an illustrative example of a widespread reluctance to condemn the regime is that it took until 2015 for the Spanish Royal Academy of History to recognise Franco as a 'dictator' in its biographical dictionary. Prior to this Franco was described as having 'erected a regime that was authoritarian, but not totalitarian'. See, for example, 'La Real Academia de la Historia modificará la definición de Franco’, El País, 7 Apr. 2015. 
José Babiano, Gutmaro Gómez, Antonio Míguez and Javier Tebar's Verdugos Impunes is in many ways the embodiment of the tension between academia and activism. Focusing on Francoism's human rights violations, the book is in fact an adaptation of a report commissioned to support the Argentinian legal case against the perpetrators of Francoist crimes, led by CEAQUA (Coordinadora de Apoyo a la Querella Argentina contra los Crimines del Franquismo). As such, Verdugos Impunes occupies an uncomfortable middle ground between historical monograph and present-day human rights inquiry. Perhaps the best example of this is the authors' insistence on the idea of the 'continuity' of Francoist violence over the course of the dictatorship. ${ }^{20}$ Verdugos Impunes's overarching argument is that 'terror was a fundamental characteristic of the regime', and that in this sense there was a 'continuity which enables us to explain Francoism in its entirety'. ${ }^{21}$ Though this line of argument perhaps makes sense within the context of the on-going court case, it is grating for the historian more familiar with scholarship on the evolution of Francoist violence, as well as more recent literature on the relationship between repression and consent. ${ }^{22}$ In fact, the detail of the authors' analysis offers more nuance than this broad emphasis on continuity might suggest, and Babiano et al. do acknowledge variations in the use of state violence over the course of the dictatorship, which surged when the regime was weakest at its beginning and end.

The continuity thesis is explored chronologically, with earlier chapters outlining the legal and administrative structures which underpinned Francoist violence during the Civil War and post-war years. This early period saw the retrospective recalibration of the term 'rebellion' to signify loyalty to the republic in what Ramón Serrano Súñer infamously dubbed 'back to front justice' (justicia al revés). ${ }^{23}$ Legislation such as the February 1939 Law of Political Responsibilities enabled the prosecution of those who had not actively supported the coup (which included retrospectively criminalising pro-Republican activity from October 1934), providing a veneer of legality for the prohibition of political parties, the purging of the state bureaucracy and the physical and economic repression of the vanquished. The book then offers an overview of the scale and nature of the human rights violations which took place after the Francoist victory in April 1939. The authors reject the idea that violence occurred within an 'action-reaction' spiral, asserting that the regime aimed to systematically eliminate those it regarded to be the enemies of Spain. ${ }^{24}$ In this sense, Verdugos Impunes sits comfortably alongside the work of Paul Preston, Francisco Espinosa and Francisco Moreno, amongst others, who have argued that the Francoist forces embarked on a systematic campaign of repression, aimed at eliminating all existing and potential opposition to the nascent regime. ${ }^{25}$

Later chapters discuss the evolution of violence during the 1960s and 1970s. The authors continue to argue the continuity of the regime's repressive character, contesting the idea that we can separate the dictatorship into an initial repressive period followed by a more peaceful era characterised by economic growth. From the late 1960s Spain saw rising unrest, particularly from student and worker movements,

20 José Babiano et al, Verdugos Impunes, 13, 117, 151.

21 Ibid., 8, 13.

22 See, for example, Ismael Saz and Alberto Gómez Roda, eds., El franquismo en Valencia. Formas de vida y actitudes sociales (Valencia: Epísteme, 1999); Ana Cabana, Xente de orde. O consentimiento cara ao franquismo en Galicia (Santiago de Compostela: tresCetres Editores, 2009); Miguel Ángel del Arco, Carlos Fuertes, Claudio Hernández and Jorge Marcos, eds., No solo miedo. Actitudes políticas y opinión popular bajo la dictadura franquista (1936-1977) (Granada: Editorial Comares, 2013); Julio Prada Rodríguez, ed., No solo represión. La construcción del franquismo en Galicia (Madrid: Biblioteca Nueva, 2014); Antonio Cazorla Sánchez, Fear and Progress: Ordinary lives in Franco's Spain (Oxford: Wiley-Blackwell, 2010).

23 Ramón Serrano Súñer, Entre el silencio y la propaganda, la Historia como fue. Memorias (Barcelona: Planeta, 1977), 245, cited in José Babiano et al, Verdugos Impunes, 61.

24 José Babiano et al, Verdugos Impunes, 89.

25 Paul Preston, The Spanish Holocaust: Inquisition and Extermination in Twentieth-Century Spain (London: Harper Collins, 2012). See also Helen Graham, The Spanish Civil War: A Very Short Introduction (Oxford: Oxford University Press, 2005); Francisco Moreno Gómez, 1936: el genocidio franquista en Córdoba (Barcelona: Crítica, 2008); Francisco Espinosa Maestre, 'Julio de 1936. Golpe militar y plan de exterminio', in Julián Casanova, ed., Morir, Matar, Sobrevivir: La Violencia en la Dictadura de Franco (Barcelona: Crítica, 2002). 
which the authorities attempted to control with an increase in arrests. The authors illustrate the multifaceted nature of state violence, which included not only the direct, physical repression of dissidents, and workers in particular, but also the refusal to ensure legal guarantees in the courts, the tolerance of police brutality and the systematic use of torture, as well as the gendered repression of women and homosexuals. This acknowledgement of gendered violence, though welcome, is also reductive in parts. The authors state that women were not only repressed for their political activism, but also for the transgression of feminine norms which this implied, notably their violation of the boundary between the public and private sphere. While there is no doubt that the trope of the mujer mala was used to smear the reputations of female activists, moving beyond the private sphere was not, in itself, sufficient basis for repression. Indeed, in Qué sabemos del franquismo Angela Cenarro shows us that despite legal and propagandistic imperatives aimed at discouraging female employment, levels remained at around 12 per cent, similar to those under the Second Republic. ${ }^{26}$

There is no doubt that greater attention to such paradoxes would have enabled Verdugos Impunes to better situate the Francoist repression within its social context and to draw out the complex social relationships which shaped, and at times facilitated, violence against the vanquished of the Civil War and the dissidents of future generations. Yet the author's final remarks remind us that it is not the book's intention to revise current historical literature on repression but rather to reflect on the presentday legal case against Francoism. The book ends with the anecdote of Maria Teresa Vilajeliu, the employee of a local tax bureau forced over many years to process the tax returns of the man who tortured her in 1975. For people like Maria Teresa, the 1977 amnesty law closed the door to restitution, and the authors advocate a re-evaluation not only of the consequences of this law, but its continuing validity. The authors' broad reliance on secondary material means that scholars of the Francoist repression are unlikely to find anything new within this analysis, though students may find it helpful as an introduction or summary of Francoism's human rights abuses.

Julio Prada Rodríguez's Plundering of the Vanquished offers an altogether more considered contribution to current scholarship on repression, which embraces recent developments in the literature on the 'grey zones' of Spanish society, those masses of Spaniards whose political ambivalence contributed to the long-term stability of the Francoist regime. ${ }^{27}$ In this book, Prada offers an outline of economic repression during the early Francoist period, from the unauthorised requisitions and pillaging of the Civil War, to attempts by the central government to impose a more ordered state of affairs with legislative innovations such as Decree no.108 and the Law of Political Responsibilities. Yet the true value of Prada's offering lies in his analysis of how legislative imperatives played out on the ground. Through a close examination of a range of bureaucratic records, including court and requisition documents, Prada allows us to glimpse 'the not always smooth relations that the regime's adherents maintained with the military powers', as well as the 'reluctance of specific sectors of the population to collaborate' with the regime.

Surviving case files reveal that a range of actors indulged in economic repression, from the military authorities and armed militias, to local extortion rings and individual opportunists, such as a guard in O Carballiño who coerced a group of prisoners into covering his bar tab at various local establishments. ${ }^{28}$ Victims were often men under the age of thirty, commonly targeted for their political and social leanings and their refusal to have supported the coup. Nonetheless, there was significant geographical variation; in Galicia, for example, regional nationalists did not make up a large proportion of victims, which stood in contrast to the more severe persecution of the PNV in the Basque Country. With regards to female victims, being associated with the Second Republic's 'modern woman' was insufficient cause for conviction through the court martial, though such perceived transgressions

\footnotetext{
26 Ángela Cenarro Lagunas, 'Visibilización, revisión y nuevas perspectivas: la historia de las mujeres y del género en la dictadura de Franco', in Ortiz Heras, ¿Qué sabemos del Franquismo?, 203.

27 The 'grey zones' will be discussed further below. See Claudio Hernández Burgos, Franquismo a Ras de Suelo: Zonas Grises, Apoyos Sociales y Actitudes durante la Dictadura (1936-1976) (Granada: Editorial Universidad de Granada, 2013).

28 Prada Rodríguez, Plundering of the Vanquished, 41.
} 
could reinforce perceptions of guilt for those under scrutiny. Perhaps of interest to historians of other contexts is that denunciation appeared to play a relatively minor role in the opening of criminal proceedings, though Prada includes the caveat that written records often omit the more informal 'tip-offs' which likely helped to drive the legal apparatus of repression. ${ }^{29}$ In addition, judges relied heavily on witnesses testifying to an individual's behaviour, and particular stock was placed in the statements of civil guards, mayors and parish priests. 'Lay' citizens also played an important role in this, which allowed some to air their personal grievances and rivalries. Nonetheless, Prada highlights that the evidence available precludes the conclusion that huge sections of the population supported the regime because they benefitted directly from the plunder of the vanquished.

Wealth was also extracted from the population through the institutionalisation of 'patriotic donations'. These were particularly valuable from a propagandistic perspective as they served to entrench the figure of the 'enemy' while helping to forge a collective Francoist identity. 'Donors' came from all socio-economic backgrounds; some gave willingly, while others contributed from a position of vulnerability in an attempt to curry favour with the new authorities. In fact, many from all backgrounds contributed only reluctantly, though this did not necessarily imply opposition to Francoism itself. Many Spaniards became weary of repeated demands for cash, while groups such as the Company of Mary in Ciudad Jardín (A Coruña) resented the donation of property central to their daily activities. As the book reaches its conclusion, Prada offers a thought provoking analysis of the defence strategies developed by the victims of economic repression. The accused had some, albeit limited, tactics for preempting financial punishment, including the timely sale of livestock, alleging the existence of debt to third parties or intentionally delaying legal proceedings by claiming ill health. Spaniards from all backgrounds often transcended the victor-vanquished division imposed from above to speak in defence of their neighbours, peers and acquaintances. Such findings testify to the strength of pre-Civil War structures of patronage, community and kinship in the post-war period, as well as the 'dynamic and unstable' character of popular attitudes during early Francoism. Most of all, Prada's research underlines the importance of 'negotiation' for understanding the behaviour of many Spaniards within the 'restricted limits of tolerance that the regime was willing to accept'. ${ }^{30}$

Carlos Fuertes Muñoz's Viviendo en Dictadura offers further insights into the complex relationship between 'ordinary' people and Francoism. In his thoroughly researched and engagingly written book, Fuertes brings further definition to Claudio Hernández's 2013 'grey zones' thesis. ${ }^{31}$ Based on an impressive source base, with particular emphasis on oral history interviews with 'ordinary people' in the Valencian region, Fuertes sheds light on a demographic category he refers to as the 'ordinary victors' (vencedores communes). This term refers to those non-elite individuals far removed from the forefront of politics, who nonetheless unequivocally identified with the coup d'état of 18 July 1936 and the subsequent Francoist victory of 1939, which they felt had restored law and order to Spain. ${ }^{32}$ Through this analytical focus, Fuertes deftly illustrates the evolution of such attitudes over time, recognising the many contradictions therein, as well as the agency and protagonism of ordinary people under the regime.

The book is separated into two parts. The first explores the extent to which the Civil War and Francoist repression shaped attitudes towards the regime, while the second focuses on the impact of the socioeconomic reforms introduced from the 1950s. Discourses which depicted the republican period as chaotic, anticlerical and violent ensured that many apolitical Spaniards considered the Civil War and dictatorship to be a 'lesser evil' (mal menor). ${ }^{33}$ Yet the Francoist 'culture of victory'

29 Ibid., 107. On the important role of denunciation in modern European History, see Sheila Fitzpatrick and Robert Gellately, 'Introduction to the Practices of Denunciation in Modern European History, 1789-1989', Journal of Modern History, 68, 4 (1996), 747-67.

30 Ibid., 190.

31 Hernández, Franquismo a Ras de Suelo.

32 Carlos Fuertes Muñoz, Viviendo en dictadura: La evolución de las actitudes sociales hacia el franquismo (Granada: Editorial Comares, 2017), 17, 31, 265.

33 Ibid., 90. 
constituted a disappointment to many even on the right, especially those who fell between the ideological cracks of the conflict, being considered too 'blue' under republican control, but too 'red' following the Francoist 'liberation'. Furthermore, Fuertes demonstrates clearly the impact of generational change on social attitudes, particularly the coming of age of Spaniards who had not known the Civil War or economic hardships of the 1940s. Support for Francoism was negatively affected by its repression of student protests from the 1960s. At this time the Franco-supporting parents of young adults caught up in this repression were forced to confront the realities of the regime's violence, something they had hitherto been protected from. Many vencedores comunes became increasingly uncomfortable with the violence of the regime, exacerbated by growing uncertainty over Spain's political future, and even fears of anti-Francoist revenge after the death of Franco. Fuertes cites Jesús Navarro Valero, born to an important business family, who expressed himself in no uncertain terms: 'I'd be the first to have my throat cut'. ${ }^{34}$ For many years the traumatic memory of the Civil War and desire for normality certainly brought the regime stability, but - by fostering a society fearful of politics - also precluded any active identification with Francoism.

The 1950s saw some improvement in socio-economic conditions compared to the 1940s, but much of the population still experienced significant economic hardship given that autarky was only abandoned at the end of the decade. The general disaffection of this period can be seen in the rise in worker and student protests from 1956. In the 1960s and 1970s anti-Francoist groups such as the PCE noted how economic growth fostered greater passivity and accommodation with the regime. Social policies, such as the introduction of social security, investment in education, Falangist leisure projects, housing policies and large infrastructure projects were generally viewed favourably by Fuertes's informants, though these often simultaneously remained critical of the regime and its excesses. 'Progress' was not necessarily considered to be the result of Francoism's competent management of the economy but rather the result of external or extra-governmental factors. Often holding down multiple jobs to support their families, informants attributed the improvement in their standard of living to their own hard graft, or else to a 'natural' sense of progress over time. Others recognised the flaws in the Francoist administration, notably the corruption of officials, or inequalities between rural and urban development. In this sense, and in yet another paradox of Francoism, while developmental policies helped to maintain the consent of the population, they were unable to convert passive conformity into the active support necessary to ensure the survival of Francoism beyond the dictator's death.

A minor critique of Viviendo en Dictadura is the slim initial justification provided for the Valencian case study. ${ }^{35}$ While it is refreshing to see a frank discussion of the practical advantages of studying the region in which the author is based, greater discussion of the merits of this geographical focus would have been welcome. For instance, many of the book's oral history informants express themselves in Valencian, and therefore some consideration of the impact of regional identity on social attitudes could have been particularly interesting. A more in-depth discussion of the specificities of the Valencian case might also have helped to mitigate the oversight of what is surely an important subcategory of vencedores communes: Francoist Civil War veterans. The many disparities between rhetoric and reality make former Civil War conscripts particularly interesting from the perspective of the regime's social support base. This omission raises a broader point about the conceptual clarity of terms like 'ordinary people', 'grey zones' or 'ordinary victors'. These are necessarily hazy given the instability of social attitudes and the changing nature of Spanish society over the course of the dictatorship, but perhaps we need to pay greater attention to who exactly is being referred to, and to trace with greater precision how the intersecting experiences of Civil War allegiance, social class, geographical origin, gender, ethnicity and other such identity markers shaped an individual's relationship with the regime. 'Ordinariness' is not an innate quality but is defined by circumstance, and should not sim-

\footnotetext{
34 Ibid., 75.

35 Fuertes is by no means alone in this practice, and similar criticism could be levelled against Prada Rodriguez's Plundering the Vanquished.
} 
ply be shorthand for those 'anonymous individuals' that we, as historians, have not heard of. ${ }^{36}$ It is up to us as historians not only to investigate shifting conceptions of 'ordinariness', but to look behind the inevitability that this label implies.

Viviendo en Dictadura also boasts a thoughtful prologue penned by Ismael Saz, which signposts a broader point worthy of comment. While Saz remarks positively on the fact that scholarship on Francoism no longer constitutes 'a type of wasteland' isolated from international historiographical trends, he laments the lack of theoretical and methodological innovations emerging from the field itself. ${ }^{37}$ David Brydan's Franco's Internationalists constitutes an excellent example of how the Francoist case can act as a springboard for re-evaluating historiographies beyond the context of modern Spain. Brydan's accessibly written and meticulously researched study of Francoist social experts is at once a history of the Francoist regime's search for legitimacy on the international stage in the 1940s and 1950s and a re-evaluation of the history of internationalism in the twentieth century. Drawing on a broad international source base, Brydan explores the role of Spanish social experts, usually medical professionals, in steering Francoist Spain through the uncertainty of the Second World War and the renegotiation of its international position amidst the isolation of the post-war years. Building on the work of Carme Molinero, Brydan's overarching argument is that the notion of Francoist Spain as a modern, 'social state' was a strategy used not only to capture support domestically but also on the international stage. $^{38}$ Doctors, nurses and social insurance specialists were important agents of this message internationally, and were therefore key to Francoism's search for international legitimacy in the years following the Spanish Civil War. At the same time the monograph also revises liberal and secular narratives of twentieth-century internationalism, testifying to the presence of an active community of 'nationalists in an age of internationalism', operating in a range of geographical spheres. ${ }^{39}$

Each of Brydan's five chapters addresses a different arena of this struggle for legitimacy: Axis internationalism before and during the Second World War, liberal organisations like the WHO after 1945, colonial Africa, Latin America and, finally, Catholic internationalism. Relationships between Spanish and German social experts during the Second World War demonstrated continuity with pre-war practice, but also the belief that 'the future of international cooperation and exchange would take place within an Axis-dominated system'. ${ }^{40}$ Depicting international health, welfare and humanitarianism as 'technical' fields separate from politics, social experts like director general of health, José Palanca were subsequently able to represent Spain as a social state worthy of international acceptance after 1945. Though initially excluded from the WHO upon its foundation in 1946, the ability of social experts to influence the organisation's structure would contribute to Spain's entry in 1951, a stepping stone to UN membership in 1955. Colonial Africa provided another setting in which Francoist health experts could showcase Spain's benevolent, civilising virtues to international observers. Such attempts met with limited success, particularly as Spanish health initiatives in northern Morocco and Spanish Guinea tended to focus on the protection of Spanish subjects, rather than the wellbeing of the colonised. Latin America was more central to the regime's international rehabilitation, and states from this region would eventually constitute the bedrock of support for Spain's accession to the UN. In Latin America, Spain could project itself as a bastion of conservative Catholic modernity, while drawing heavily on the more traditional concept of Hispanidad. ${ }^{41}$ It was this combination of the traditional and the modern which made Francoist social experts such important vectors of Spanish cultural

\footnotetext{
36 Prada Rodríguez, Plundering of the Vanquished, 14.

37 Ismael Saz, 'Prólogo', in Fuertes, Viviendo en Dictadura, xii. This point is also raised by Ana Cabana Iglesia, in Ortiz Heras, Qué sabemos del franquismo, 89.

38 Carme Molinero, La captación de las masas: política social y propaganda en el régimen franquista (Madrid: Cátedra, 2005).

39 David Brydan, Franco's Internationalists: Social Experts and Spain's Search for Legitimacy (Oxford: Oxford University Press, 2019), 176.

40 Ibid., 21.

41 The term Hispanidad refers to the historical, colonial, cultural, linguistic, religious, social and political ties between Spain and Hispanic America. The concept gained increased prominence under Francoism, particularly during the regime's initial period of international isolation.
} 
diplomacy in Latin America, where, despite opposition from republican exiles, the regime could promote an Ibero-American 'third way' between communism and the capitalist welfare state. Broad sympathy for Francoist Spain amongst the international Catholic community, particularly in the context of the Cold War, facilitated the promotion of Francoist Spain as the 'spiritual reserve of the West'. In this sense, while existing scholarship offers a broadly secular narrative of post-war internationalism, Franco's Internationalists highlights the relevance of religious interests to a broad range of secular international institutions well into the twentieth century.

While Franco's Internationalists focuses on the professional lives of Francoism's social experts, Brydan might have offered a greater sense of their personal agency and reflections on their time spent abroad. There is an intriguing contradiction in the fact that these ambassadors of Francoism chose to spend so much time outside of Spain and its socio-political confines, and this reviewer was particularly curious to learn more about the day-to-day lives of, for example, the nearly 16,000 Francoist female missionaries based in Latin America, Africa and Asia. ${ }^{42}$ Notwithstanding this comment, Brydan's study not only demonstrates the intellectual benefits of confronting the regime's paradoxes, but also reminds us that Spain's recent experiences of dictatorship are fertile ground for producing paradigm-shifting interventions within a range of international historiographical fields.

Recent discussions of Spain's modern history have warned against overstating the country's exceptionality within its continental context. ${ }^{43}$ Studies of Spain's protectorate in northern Morocco have, for example, muddied conceptual distinctions between Franco's authoritarian regime and its democratic European neighbours, while Spain's fraught historical memory debates are not so dissimilar from discussions in other European nations which have recently known civil war. ${ }^{44}$ Yet it would be a mistake to understate the potential of the Spanish perspective to reinvigorate current debates in the historiography of modern Europe. The influence of National Catholicism on countless aspects of life under the dictatorship offers rich opportunities for challenging secularising narratives in all manner of fields, as Brydan's work reviewed here indeed illustrates. The history of gender, sexuality and the body can also be enriched through greater attention to the impact of political and cultural Catholicism on understandings of femininity and masculinity in the modern period. ${ }^{45}$ Furthermore, the fact that the political cleavages of the Civil War upset pre-existing social hierarchies renders Francoist Spain a productive context in which to test the intersectional turn in social history, notably the impact of Spain's socio-political context on notions of gender, class, sexuality, disability and racial privilege. ${ }^{46}$ For historians of the Cold War, Francoist Spain's often greater identification with its Latin

42 Ibid., 161-3.

43 See, for example, contributions to the Journal of Contemporary European History's recent roundtable on the Spanish Civil War, in particular: Eduardo González Calleja, 'The Spanish Civil War: New Approaches and Historiographic Perspectives', Contemporary European History, 29 (2020), 265-6; Giuliana Chamedes, 'Transnationalising the Spanish Civil War', 263; Helen Graham, 'On Historicising the War in Spain', 270.

44 Eric Storm and Ali Al Tuma, eds., Colonial Soldiers in Europe, 1914-1945: Aliens in Uniform in Wartime Societies (New York: Routledge, 2016); Rocío Velasco de Castro, "La imagen del "moro" en la formulación e instrumentalización del Africanismo franquista', Hispania, 74, 246 (2014), 205-36; Antonio Cazorla Sánchez, 'From Ideological to Humanistic Interpretations', Contemporary European History, 29 (2020), 260.

45 See, for example, Mary Vincent, 'Made Flesh? Gender and Doctrine in Religious Violence in Twentieth-Century Spain', Gender and History, 25, 3 (2013), 668-80; Nerea Aresti, 'Masculinidad y nación en la España de los 1920 y 1930', Mélanges de la Casa de Velázquez, 42, 2 (2012), 55-72; Richard Cleminson, 'Iberian Eugenics? Cross-overs and Contrasts between Spanish and Portuguese Eugenics, 1930-1950', Dynamis, 37, 1 (2017), 89-110; Yvonne Maria Werner, ed., Christian Masculinity: Men and Religion in Northern Europe in the $19^{\text {th }}$ and $20^{\text {th }}$ Centuries (Leuven: Leuven University Press, 2011).

46 See, for example, Richard Cleminson, 'Stonewall and its Legacy in Iberia', History Workshop Journal, 89 (2020), 214-9; Javier Fernández Galeano, 'Is He a "Social Danger?": The Franco Regime’s Judicial Prosecution of Homosexuality in Málaga under the Ley de Vagos y Maleantes', Journal of the History of Sexuality, 25, 1 (2016), 1-31; Stephanie Wright, 'Glorious Brothers, Unsuitable Lovers: Moroccan Veterans, Spanish Women and the Mechanisms of Francoist Paternalism', Journal of Contemporary History, 55, 1 (2020), 52-74. On intersectionality, see Kimberlé Crenshaw, 'Mapping the Margins: Intersectionality, Identity Politics, and Violence Against Women of Color', Stanford Law Review, 43, 6 (1991), 1241-99. 
American partners than with its neighbours in Western Europe forces us to re-evaluate current wisdom on bipolarity and the division of Europe during the twentieth century. ${ }^{47}$ In short, as a regime which straddled 1930s fascism, the Cold War, decolonisation, the modernising imperatives of the Catholic Church of the 1960s and accelerating European integration, Francoism offers a valuable longterm vantage point on twentieth-century European history from the perspective of one of the continent's most enduring right-wing dictatorships. In this sense, while drawing insights from the ordinary, we would do well not to overlook the more extraordinary aspects of Francoism's trajectory within the modern history of Europe, and the wider methodological innovations these might engender.

Acknowledgements. I am grateful to the following people for their insightful feedback on earlier drafts of this review article: Aaron Ackerley, Matthew Kerry, Harry Mawdsley, Stephen Rainbird and Mary Vincent. I would also like to thank the Wellcome Trust for their ongoing support, as well as the editors of Contemporary European History for their helpful comments. Finally, thank you to my mother, Maryse Wright, for her support and company as I wrote this piece under the lockdown.

\footnotetext{
47 On Hispanidad and relations between Francoist Spain and Latin America, see, for example, Johannes Großman, “Baroque Spain” as metaphor. Hispanidad, Europeanism and Cold War Anti-Communism in Francoist Spain', Bulletin of Spanish Studies, 91 (2014), 755-71; Raanan Rein, La salvación de una dictadura. Alianza Franco-Perón, 1946-1955 (Madrid: Consejo Superior de Investigaciones Científicas, 1995); Lorenzo Delgado Gómez, Imperio de papel: acción cultural y política exterior durante el primer franquismo (Madrid: Consejo Superior de Investigaciones Científicas, 1992); Eduardo González Calleja and Fredes Limón Nevado, La Hispanidad como instrumento de combate. Raza e Imperio en la prensa franquista durante la Guerra Civil española (Madrid: CSIC, Centro de Estudios Históricos, 1988).
}

Cite this article: Wright S (2021). Out of the Ordinary: Confronting Paradox in the Historiography of Francoism. Contemporary European History 30, 136-146. https://doi.org/10.1017/S0960777320000478 